\title{
LAND REGISTRATION OF PROPERTY RIGHTS IN THE REVIEW OF THE ECONOMICS VALUE
}

\author{
Elviana Sagala ${ }^{1}$, Ade Parlaungan Nasution2, Risdalina ${ }^{1}$ \\ ${ }^{1}$ Sekolah Tinggi Ilmu Hukum Labuhan Batu \\ ${ }^{2}$ Sekolah Tinggi Ilmu Ekonomi Labuhan Batu
}

\begin{abstract}
The importance of registration of land rights for every person or legal subject to proof of ownership certificate of property rights for economic value will be on the increase in value and simplify every business economy to obtain their capital and to increase its business, because the registered land can be used as collateral to obtain venture capital in the Bank or other financing that is set in the legislation.And ignorance of the importance of registration of land rights on the property of factors primarily the many people who do not understand the importance of registration of land rights, and the lack of socialization Government to the public or the cooperation of village government and village by Lecturer of Law and Lecturer in Economic Law by asking lecturers in the area The conduct of devotion in the village and his village.
\end{abstract}

Keywords : Land registration, Property Right, Economics

\section{Introduction}

Economic development, as part of national development which is an effort to realize the people's welfare fair and prosperous based on Pancasila and the State Constitution of 1945.

In regard to maintaining the sustainability of development, which is the culprit includes both government and society as individuals and legal entities, it is necessary to fund in large numbers. With the increase in development activities of course also increases the need for the availability of funding, mostly obtained through bank credit.

Once the importance of these funds in the development process as well as to the welfare of society, it is personal, then in this case the regulation of protection through a strong guarantee rights institutions and provide legal certainty so is important for the giver and receiver as well as other parties.

It has been showcased in Act No. 5 of 1960 About the Basic Regulation of Agrarian paragraph 51 which states: Mortgage charged to property, the right to cultivate and building rights mentioned in Article 25, 33, 39 set in Constitution. And the law has not been formed by the long time that is less than 30 years with the formation of Mortgage Law No. 4 of 1996 on April 9, 1996, regarding Encumbrance Top Museums Relating to Land. Which were previously 
on the security rights are set in the Book of the Law of Civil Law (Civil Code), as regulated in Article 57 of the Basic Agrarian Law which reads Over The law on security rights pursuant to Article 51 has not been formed,

As the purpose of the security rights according to Law No. 4 of 1996, namely Article 1 paragraph (1) which reads Mortgage on land and objects relating to the soil, which in turn called security right is a guarantee imposed on the right to land as intended in Act No. 5 of 1960 on the Basic Regulation Agrarian, following or not following other objects that are installed on the ground, for the repayment of certain debt, which gives standing to certain creditors to other creditors.

Meanwhile, another definition of Guarantee Mortgage is Right for the land to a particular debt settlement, which gives precedence to the position of certain creditors to other creditors. In the sense that if a debtor in default, creditors' security rights holder the right to sell by public auction the land as collateral under the terms of the current legislation prundang, with mendahulu rights than other creditors, the primary position must necessarily precede the state as tax receivables. In the case of ground objects which can impose security rights enshrined in article 4 Mortgage Act law, which reads as follows:

(1) The right to land that can be loaded Encumbrance is:
a. Right of ownership;
b. Cultivation Rights;
c. Building rights.

(2) In addition to the rights on the land referred to in paragraph (1), the right to use the land State under prevailing provisions shall be registered and transferable by their nature can also be burdened Mortgage right

(3) Encumbrances Encumbrance on the right to use the land Properties will be further regulated by Government Regulation.

(4) Mortgage can also be imposed on the right to land and buildings, plants, and works that have been or will there is a unity to the land, and that of land-rights holders who deducted expressly stated in the Deed granting Mortgage concerned. 
(5) If the buildings, plants, and works as referred to in paragraph (4) not owned by the holder of land rights, the imposition of Encumbrance on these objects can only be done with the signing and on the Deed Granting Mortgage concerned by the owner or which are authorized for that by him with an authentic deed.

That the property is right down by the strongest and most that can possess by people on the ground with the provisions of Article 6, and the property can be switched and transferred to another party it can be seen of Article 20 of the Basic Agrarian Law.

Sometimes people do not understand what exactly the certificate, because most people registering their land rights because of economic necessity that is a guarantee in the bank for the loan guarantee its debts then register their rights with the help of the Bank and the Acting Deed Land partners with the Bank.

While in the case of registration of land are clear economic value advantageous, because it can be used to take the money made by the person or subject the law to suit his needs by law is not prohibited to it.

\section{OBJECTIVE :}

1. Why are people still many who have not registered their land rights at the National Land Agency / Office Land?

2. What is the relationship of land rights registration of property rights with economic value?

\section{DISCUSSION}

\section{A. Definition Land Registration}

In order to provide legal certainty and legal protection of property rights over land, in accordance with Government Regulation No. 24 of 1997 on Land Registration, government should register the entire plot in Indonesia either by a systematic approach and sporadic.

Registration of land as the wording of Article 1 point 1 Regulation Orders No. 24 of 1997 concerning the registration of the land, namely: land registration is a series of activities carried out by the Government continuously, continuous and regular, covering the collection, 
processing, bookkeeping and presentation as well as the maintenance of physical data and data juridical, in the form of maps and lists, on plots and units of flats, including the provision of a letter of buki rights for plots of existing rights and ownership of the apartment units as well as certain rights which encumber juncto Article 19 of the registration of the land, namely:

Paragraph (1) to ensure legal certainty by diadakam government land registration throughout the territory of the Republic of Indonesia according to the provisions stipulated in Government Regulation.

Paragraph (2) the registration under subsection (1) of this article include:

a. Measurement, mapping and soil bookkeeping;

b. Registration of rights to land and transfer of such rights;

c. Award letters are valid proof of rights as a tool evidentiary

Paragraph (3) registration of land held by the State and society given the state of traffic purposes 4iding economical as well as the possibility of its implementation, according to the Minister of Agrarian consideration.

However, it should also be in the know that the history of the development of land registration in Indonesia is often divided into four historical are:

a. Land registration Pre-Colonization Era

b. Land Registry Colonization Era

c. Land Registry Independence Era

d. Land Registry Era Basic Agrarian Law (Basic Regulation of Agrarian Affairs)

History of land registration is a rule that is the basis for the formation of Law Agrarian, where registration of land in the era of pre history, registration of land based on customary law and that was before the colonial era as they set out in Article 22 of Law Agrarian, while land registration era colonial rule that is used is the rule in the state of invaders, but in this case happens dualism that is to invaders then used Law colonizers, and to the earth's son used indigenous rights, the era of independence that time regulations were born and who gave birth to a decision President number 55 of 1955 on the establishment of the Agrarian Ministry in conjunction with Presidential Decree No. 190 of 1957 dated June 1, 1957, the Bureau of Land Registration in the Ministry of Agrarian diverted to the task:

a. Surveying, mapping, and registration of all land in Indonesia

b. Bookkeeping rights to land as well as recording the transfer of these rights 
And that applies skarang the era of the Basic Agrarian Law. Then the registration of land is one of the people's right to defend their rights in the ownership of a land plot.

\section{REGISTRATION PROCESS OF LAND}

To register rights over our land register to the land office where the location of the land. In this case we would have to prepare all the requirements in full, and this is often not known by the public and are reluctant to register their land, in addition to not know as well as the Land office layout that far. As for the conditions which must be prepared by the public or law subject who want to register their land rights, about the rights Reserved.

Registration of land known as the two forms of land registration as referred to in Article 13 of Government Regulation No. 24 of 1997 which is on land registration for the first time reads as follows:

- Paragraph (1) registration of land for the first time implemented through systematic land registration and land registration sporadic.

- Paragraph (2) systematic land registration is based on a work plan and implemented in the areas determined by the Minister

- Paragraph (3) in the case of a rural / village have not been designated as the systematic land registration area as referred to in paragraph (2), the registration is carried out through sporadic registration.

- Paragraph (4) Sporadic land registration carried out at the request of an interested party.

difference of both the registration is that if the initiative to register it is the Government, which in a certain area, simultaneously all sertipikatnya created land, then it is called a systematic registration or if this time is known as Systematic Land Registry Direct (PTSL)

If the initiative to register the land comes from the land owner while after waiting for some time no government program to obtain a certificate of land in the region, then the landowner can take the initiative to apply for registration / certification of the land at the local Land Office. This is called sporadic land registration.

Land Registry activity (Article 14-22 of Government Regulation 24/1997) itself is divided into: 
1. Basic map-making registration, In this process, carried out the installation, measurement, mapping land national engineering maintenance base point. From this basic map is made registration 1

2. Delimitation of land parcels, To avoid disputes regarding land ownership limit somewhere, between the owner and the other owners of adjacent, each is required to be made the boundaries of land ownership (in the form of iron or wood). In setting such limits, usually always has to be an agreement regarding the boundaries with adjacent land owners, which in legal terminology is known as contradictio limitative

3. Measurement and mapping of land areas and mapping registration of these boundaries, measurements for widely known sure. If there is a vast difference between the amount of land labelled on girik letter/letter other ownership with the measurement results Office Land, the land owner can take two alternatives:

a. agree with the results of measurements of the land office, If you agree, then the landowner stay signed statement on the extent of land he owned and which will be filed as the certification basis.

b. filed an objection and request a reassessment lands located next to the property.

To prevent disputes about the boundaries, makapada time measurements to be made by the land office, usually the land office requires the owner of the land (or their proxies) hadirdan witness these measurements, attended also by RT (neighborhood Association chief)/RW (citizens Association chief) or representatives from the local village.

1. Making a list of land

Plots that have already been mapped or affixed numbers registration on the registration map is recorded in the land register

2. Making the measurement certificate.

Measure Letter manufacture the end product of the activities of collection and registration of land, which will be used as the basis for issuing land titles. 
The requirements to apply for registration of sporadic namely:

1. Application letter from the landowner to undertake certification of competent law his estate.

2. The power of attorney (if the management is delegated to others).

3. Identity of land owner (the applicant), legalized by the competent public authority (usually notaries) and proxies

a. for individuals: copy of ID card and Family Registration Card (KK) while

b. legal entity (in this case Corporation / Foundations / Cooperatives): Statutes

follows the entire change-amendment and approval authorities from minister

4. Evidence filed land rights, which are:

a. mail proof of property rights issued under the autonomous rule in question

b. ownership certificate issued by the Foreign Investment No. 9/1959

c. decree granting property rights of authorized official, either before or since the enactment of the Basic Agrarian Law, which was not accompanied by an obligation to register the rights granted, but have met all the obligations referred to therein.

d. Petok taxes / Landrente, girik, pipil, ketitir and Verponding Indonesia before the enactment of Government Regulation No. 10/1961

e. Deed of transfer of rights created under the hand that bore the testimony by the Customary Chief / Head of Village / village created before the enactment of Government Regulation No. 10/1961, accompanied by the right base to be diverted, or

f. Deed of transfer of land made by PPAT whose land has not been recorded, accompanied by the right base to be diverted, or

g. Waqf deed of pledge / deed of pledge substitute endowments / letter endowment pledges made before or since commenced PP 28/1977 with pedestal disert5ai diwakafkan rights, or the minutes of the auction made by the officials authorized Auctions, whose land has not been written off, accompanied by the right base at the switch, or

h. Letter of appointment or purchase a replacement parcel of land taken by local governments, or

i. Minutes of the auction made by the officials authorized auction, the land is not yet recorded, accompanied by the right base to be diverted, or 
j. The certificate of land history ever made by the Office of Land and Building Tax, accompanied by the right base to be diverted and legalized by the competent authority, or

k. Other forms of written verification tool by whatever name called as referred to in Article II, Article VI and Article VII provisions of the Basic Agrarian Law conversion, or

1. Letters other evidence of ownership, published and take effect before the enactment of the Basic Agrarian Law (and legalized by the competent authority - in this case usually local village chief), or

m. Other evidence, what if there is no proof of ownership, which are: Statement of Physical Mastery over 20 years continuously and certificate with Village chief witnessed by 2 elders / locals

5. The Statement has been put up boundary markers

6. A copy of the UN SPPT (tax return payable letter) current year

7. Photocopy Decree of Location Permit and certificate of location (if the applicant is a legal entity)

8. Registration base map making, In this process, carried out the installation, measurement, mapping and maintenance of national technical basis points. From this base map created map registration

9. Delimitation of land parcels

Here are the stages of implementation PTSL which is divided into several stages, namely:

1. Extension: This extension will be scheduled in advance and carried out by national land Agency (National Land Agency (BPN)) officers residing in rural areas or villages;

2. Data Collection: thereafter counseling, then the officer will perform data collection to the public by asking the status of land ownership, how the acquisition of the land, whether of inheritance, donation or purchase and proof of deposit Tax on Acquisition of Land and Building and income tax (except for people who can not afford waived for these costs ) has been paid;

3. Measurement, after passing through the administrative process and is said to qualify, then the officer will take measurements. The measurements include the length and breadth of the land owned, the limiting boundary that has received approval from the owners of neighboring land, form fields and also vast areas of land; 
4. A committee session: This session consisted of national land Agency (National Land Agency (BPN)) and one representative from the village or villages. The purpose of this provision is to examine the trial juridical data, field inspection, noting the disclaimer, draw conclusions and to obtain additional information;

5. Announcement and Endorsement: after passing through committee hearings, the committee will announce the result, then the clerk will approve their approximately 14 days after the announcement was posted at the village or district office or the local land office. If within 14 days after the announcement, there is no objection, meaning safe registered land, not land disputes and can proceed to the issuance of the certificate. The announcement shall at least contain the name of the owner of the land, land area, where the soil and the ground plane;

6. Issuance of Certificate: One final stage of certificate issuance by the Ministry of Agrarian Spatial / National Land Agency being authentic proof someone on his land ownership shared directly with landowners.

The cost for this program is charged to the government, or in other words free (no charge). Participants PTSL only charged to pay for the provision of land titles to the land that do not have land titles, manufacture and installation of boundary markers, Tax on Acquisition of Land and Building (BPHTB) if exposed, and others such as stamp duty, photocopying Letter C or witness fees.

From the description above it is not difficult to register land ownership in order to obtain legal certainty.

\section{Definition Rights Liability}

As the purpose of the security rights according to Law No. 4 of 1996, namely Article 1 paragraph (1) which reads right Dependent on land and objects relating to the soil, which in turn called security right is a guarantee imposed on the right to land as intended in Act No. 5 of 1960 on the Basic Regulation Agrarian, following or not following other objects that are installed on the ground, for the repayment of certain debt, which gives standing to certain creditors to other creditors. 
Meanwhile, another definition of Guarantee Mortgage is Right for the land to a particular debt settlement, which gives precedence to the position of certain creditors to other creditors. In the sense that if a debtor in default, creditors' security rights holder the right to sell by public auction the land as collateral under the terms of the current legislation prundang, with mendahulu rights than other creditors, the primary position must necessarily precede the state as tax receivables.

In the case of imposition of mortgage there are things to note are:

1. Their object security rights (Article 4 Law On Mortgages)

2. Their dependents providers and rights holders (Article 8 Law On Mortgages)

3. Granting security rights (Article 10 to 13 Law On Mortgages)

4. Issuance of mortgage certificates (Article 14-15 Law On Mortgages)

5. Transition security rights (Article 16-17 Law On Mortgages)

6. Clear its Encumbrance (Article 18-19 Law On Mortgages)

7. Execution security rights if the breach of contract or tort (Article 20-21 Law On Mortgages)

8. Mortgage write-off (Article 22 Law On Mortgages)

Then in such matters, is article 4 Law On Mortgages have established land rights, including property rights that may be charged encumbrance.

\section{Land Deed Official Definition (PPAT)}

Of course we want to know how the objects guarantee that we have the assurance in the bank for a certain debt borne security rights to the land office that certificate as proof of ownership of our right to the land have legal certainty, so in this case Deed Official Land which is also a Notarislah which makes loading encumbrance certificate) to be enrolled into the National Land Agency/Office Land where the object of the guarantee is located. In this case we can see the government regulation number 37 of 1998 Concerning the Rules of Land Deed Official Position.

\section{Definition OF Economy}

Economic law is divided into two, namely:

a. Development of economic law, namely the entire regulatory and legal thinking on ways to increase and the development of economic life (eg law firms and investment law) 
b. Social economic law, namely the entire regulatory and legal thinking on the ways of economic development revenue sharing fairly and equitably, in accordance with human rights (eg, labor law and housing law)

Economics is the study of human behavior in selecting and creating prosperity. The core economic problem is the imbalance between human needs that are not limited by the means of satisfying the needs of a limited number. The problem that then causes scarcity.

Economic law is a causal relationship or affinity economic events that are interconnected with one another in the daily economic life of society. The economy will always talk about the capital to achieve the welfare of society or individual persons or legal entity.

Land ownership is also an investment or an object into a primary necessity for every person will always think will have a good ground for a place to stay, for business, or for agricultural plantations.

Of course for that matter any person or legal Liberation must understand how to ensure legal certainty over the ownership of the land.

Then the registration of land rights is the thing to do for menajmin rule of law and also for the sake of that money bought dlam acquire such land can be taken by way of megagunkan object to the Bank and obtained money in the form of debt that can be used as capital, land remains controlled and the money can be in modalkan for survival including repayment of debt repayments.

\section{RELATIONSHIP OF LAND REGISTRATION ON THE PROPERTY OF THE ECONOMICS}

From the description above, we will be able to understand and be understood that the land registration so is important and has economic value.

Because the land can not be separated from the Economy, for every person or legal subject had always wanted to own land but do not reduce their capital and profits still not diminished but made for mosal extra effort so that businesses increasingly growing and Welfare services are met. 
To find capital for economic players is not difficult, when it had registered land because they can be used as collateral at the Bank if the land is registered land, because the Act encumbrance juncto Agrarian Law can only charge encumbrance and have legal certainty when the land is registered land.

For the registration of land is very important for ssetiap person or legal subject because whenever necessary will be able to provide economic value in the form of money to bail for registered land ownership rights for the community.

Therefore should any person or legal subjects do not again did not register their land rights so as to have proof of ownership in the form of certificates of property rights.

\section{CONCLUSIONS AND RECOMMENDATIONS}

\section{A. CONCLUSION}

The importance of registration of land rights for every person or legal subject to proof of ownership certificate of property rights for economic value will be on the increase in value and simplify every business economy to obtain their capital and to increase its business, because the registered land can be used as collateral to obtain venture capital in the Bank or other financing that is set in the legislation.And ignorance of the importance of registration of land rights on the property of factors primarily the many people who do not understand the importance of registration of land rights, and the lack of socialization Government to the public or the cooperation of village government and village by Lecturer of Law and Lecturer in Economic Law by asking lecturers in the area The conduct of devotion in the village and his village.

\section{B. RECOMMENDATIONS}

The government should be more aggressive to jump directly to the area where the region to provide socialization to regions according to the observations he Government of the area is still a lot that has not been registered and the government of the village and village to the MOU (Memorandum of Understanding) or a request for Lecturer of Law and Lecturer of Economics her area do devotion and research as well as provide pemamparan about what is needed of the village so that people know what is considered the village government and village's especially 
important about the importance of land registration of property rights of economic value, and a guarantee of legal certainty, do not actually afraid because it will reduce the occurrence of the sale and purchase under the hands of known village government and village.

\section{BIBLIOGRAPHY}

\section{BOOKS}

Adjie, Habib. 2018. Hak Dependents As Guarantee Institute of Land, Molds to -1, CV. Mandar Maju: Bandung

Chandra, S.2005. Certificate of Ownership Rights to Land, Molds First, PT Grasindo: Jakarta

Harsono, Budi. Agrarian Law 2009. Indonesia: History of the Formation of the Basic Agrarian Law, Content and Implementation, Molds to 9: Jakarta

Lubis, Mhd Yamin \& Lubis Abd Rahim. Land Registry Law 2010. Revised Edition, CV. Mandar Maju: Bandung

Lubis, Mhd Yamin \& Lubis Abd Rahim. 2011.Pencabutan Rights, Liberation, and the Land Acquisition, CV. Mandar Maju: Bandung

Sutedi, Adrian.2010. Legal Mortgage, First Edition, Sinar Graphic: Jakarta

Sutedi, Adrian.2011. Certificate of Land Rights, First Edition, Sinar Graphic: Jakarta

\section{Constitution}

Act of 1945

Law No. 5 of 1960 About the Basic Regulation Pokk Agrarian

Act No. 4 of 1996 on the Rights Tanggungann By Land

Government Regulation No. 24 of 1997 on Land Registration

Government Regulation No. 37 Year 1998 on the regulations Land Deed Official Position

The set of Regulations Title Deed Official Land

\section{INTERNET}

https://irmadevita.com/2019/pendaftaran-tanah-sistematis-lengkap-ptsl/

https://irmadevita.com/2009/pensertifikatan-tanah-secara-sporadik/

https://www.maxmanroe.com/vid/bisnis/pengertian-ekonomi.html 